\title{
Calibration and simulation of two large wastewater treatment plants operated for nutrient removal
}

\author{
J. Ferrer*, J.J. Morenilla **, A. Bouzas*** and F. García-Usach* \\ * Dpto. Ingeniería Hidráulica y Medio Ambiente. Universidad Politécnica de Valencia. Camino de \\ Vera s/n. 46022. Valencia. Spain \\ (E-mail: jferrer@hma.upv.es; magarus@hma.upv.es) \\ ** Entidad de Saneamiento de Aguas Residuales de la Comunidad Valenciana. Álvaro de Bazán \\ 10. 46010. Valencia. Spain. \\ (E-mail: morenilla_jos@gva.es) \\ *** Dpto. Ingeniería Química. Universidad de Valencia. Doctor Moliner 50. 46100. Burjassot. \\ Valencia. Spain \\ (E-mail: alberto.bouzas@uv.es)
}

\begin{abstract}
Control and optimisation of plant processes has become a priority for WWTP managers. The calibration and verification of a mathematical model provides an important tool for the investigation of advanced control strategies that may assist in the design or optimization of WWTPs. This paper describes the calibration of the ASM2d model for two full scale biological nitrogen and phosphorus removal plants in order to characterize the biological process and to upgrade the plants performance. Results from simulation showed a good correspondence with experimental data demonstrating that the model and the calibrated parameters were able to predict the behaviour of both WWTPs. Once the calibration and simulation process was finished, a study for each WWTP was done with the aim of improving its performance. Modifications focused on reactor configuration and operation strategies were proposed.
\end{abstract}

Keywords

Activated sludge plants; ASM2d; biological nutrient removal; calibration; upgrade.

\section{INTRODUCTION}

In recent years, the number of wastewater treatment plants (WWTPs) equipped with nutrient removal is increasing worldwide. Several models have been developed to aid the design, operation and research in biological wastewater treatment systems: ASM2 (Henze et al., 1995), ASM2d (Henze et al., 1999). The verification of a mathematical model provides an important tool for the investigation of advanced control strategies that may assist in the design or control of WWTPs. ASM2d is a mechanistically model that describes the dynamic and stationary behaviour of the processes involved in the biological wastewater treatment. This model has been found as very successful in describing the behaviour of activated sludge processes for nutrient and organic matter (COD) removal.

The strict standards for treatment plant effluents in Comunitat Valenciana (Spain), particularly ammonia concentration lower than $1 \mathrm{mg} \mathrm{N}-\mathrm{NH}_{4} \mathrm{l}^{-1}$, require better process control. Mathematical models are necessary to elaborate optimising strategies. The aim of this work was the calibration of the ASM2d for two full scale biological nitrogen and phosphorus removal plants in order to characterize the biological process and to upgrade the plants performance. 


\section{METHODS}

\section{Plants description}

The wastewater treatment plants studied in this paper were designed, initially, for organic matter and nitrogen removal from domestic and industrial wastewater of two communities located in the Mediterranean coast of Spain.

The wastewater treatment plant of Elche-Algorós (198 000 P.E.) is a two-stage $(\mathrm{A}+\mathrm{B})$ plant, following preliminary treatment. In stage A, non-settled sewage is introduced in two parallel activated sludge lines equipped with diffused aeration. After settling, the wastewater is introduced in a single activated sludge line (stage B) divided into three tanks: a non-aerated tank (denitrification tank) and two mechanical surface aerated tanks with different dissolved oxygen concentrations (nitrification tanks).

Elda-Vall del Vinalopó WWTP (161 000 P.E.) consists of two parallel activated sludge reactors, each one divided into an anoxic and an aerobic zone, following preliminary treatment and primary clarification. The air is supplied to the aeration zone by means of a diffused aeration system. The anoxic and aerobic zones were designed as completely mixed reactors. Horizontal-axis propeller agitators secure circulating and mixing in anoxic chambers.

\section{Measurements}

Application of the ASM2d model to full scale WWTPs requires experimental data on activated sludge and wastewater characteristics. During four weeks, a 24-hour "continuous" measurement campaign was carried out in order to obtain wastewater samples from reactor influent, mixed liquor and reactor effluent. Wastewater samples were grabbed every two hours at the selected locations. For the influent and effluent characterization the following parameters were analysed: total suspended solids (TSS), volatile suspended solids (VSS), COD total, $\mathrm{COD}_{\text {filtered, }} \mathrm{BOD}_{1}$ total, $\mathrm{BOD}_{\mathrm{l}}$ filtered, volatile fatty acids (VFA), $\mathrm{NO}_{3}-\mathrm{N}, \mathrm{NH}_{4}-\mathrm{N}$, total nitrogen $\left(\mathrm{N}_{\text {tot }}\right)$, total phosphorus $\left(\mathrm{P}_{\text {tot }}\right), \mathrm{PO}_{4}-\mathrm{P}$ and alkalinity (Alk). Mixed liquor suspended solids (MLSS), mixed liquor volatile suspended solids (MLVSS), COD total, $\mathrm{NO}_{3}-\mathrm{N}, \mathrm{NH}_{4}-\mathrm{N}$, filtered total nitrogen $\left(\mathrm{N}_{\text {tot filtered }}\right)$, total phosphorus $\left(\mathrm{P}_{\text {tot }}\right), \mathrm{PO}_{4-}$ $\mathrm{P}$ and alkalinity were determined for sludge characterization. The average measurement results are presented in Table 1. All necessary "on-line" recordings (flowrates, DO) were also collected for the calculations.

Although Elche WWTP was designed for biological nitrogen removal, this process proved to be unstable and not efficient to reach the effluent requirements. Nitrification occurred randomly, converting the theoretical denitrification tank into an anaerobic tank. Due to this fact, biological phosphorus removal took place as show the results of the WWTP sampling period (Table 1). This behaviour was verified with historical data provided by the plant operator.

At Elda WWTP nitrification was achieved as the ammonia concentration in the effluent flow indicates. In spite of the lack of an anaerobic zone, the results listed in Table 1 suggested the presence of phosphorus accumulating organisms (PAOs).

\section{Analytical methods}

Most of the analytical techniques used were in accordance with Standard Methods (1998) (TSS, VSS, COD, $\left.\mathrm{NH}_{4}-\mathrm{N}, \mathrm{P}_{\text {tot }}, \mathrm{PO}_{4}-\mathrm{P}\right)$. COD (10-125 mg l$\left.{ }^{-1}\right)$, $\mathrm{NO}_{3}-\mathrm{N}$ and Total $\mathrm{N}$ were determined with specific MERK kits. Short chain fatty acids were determined by titration using a method proposed by WRC (1992). BOD was determined by pressure measurements using a WTW OXITOP CONTROL system. 
Table 1. Influent, activated sludge and effluent average data.

\begin{tabular}{|c|c|c|c|c|c|c|c|c|c|c|}
\hline \multirow{2}{*}{ Parameter } & \multirow{2}{*}{ Unit } & \multicolumn{3}{|c|}{ Elche A } & \multicolumn{3}{|c|}{ Elche B } & \multicolumn{3}{|c|}{ Elda } \\
\hline & & Infl. & Sludge & Eff. & Infl. & Sludge & Eff. & Infl. & Sludge & Eff. \\
\hline TSS & $\mathrm{mg} \mathrm{l}^{-1}$ & 366 & 2428 & 63 & 86 & 2113 & 19 & 121 & 3772 & 22 \\
\hline VSS & $\mathrm{mg} \mathrm{l}^{-1}$ & 289 & 1917 & 54 & 74 & 1522 & 15 & 103 & 2905 & 18 \\
\hline $\mathrm{COD}_{\text {total }}$ & $\mathrm{mgCOD} \mathrm{l}^{-1}$ & 939 & 3942 & 375 & 419 & 2327 & 71 & 645 & 5025 & 84 \\
\hline $\mathrm{COD}_{\text {filtered }}$ & $\mathrm{mgCOD}^{-1}$ & 366 & --- & 285 & 317 & --- & 57 & 376 & --- & 58 \\
\hline $\mathrm{BOD}_{\text {l total }}$ & $\mathrm{mgCOD} \mathrm{l}^{-1}$ & 710 & --- & 303 & 380 & --- & 33 & 533 & --- & 24 \\
\hline $\mathrm{BOD}_{\text {l filtered }}$ & $\mathrm{mgCOD} \mathrm{l}^{-1}$ & 300 & --- & 245 & 288 & --- & 26 & 318 & --- & 2 \\
\hline VFA & $\mathrm{mgCOD} \mathrm{l}^{-1}$ & 0 & --- & 0 & 0 & --- & 0 & 91 & --- & 0 \\
\hline $\mathrm{NO}_{3}-\mathrm{N}$ & $\mathrm{mgN} \mathrm{l}^{-1}$ & 0.7 & 0.6 & 0 & 0 & 0.2 & 0.5 & 0 & 19.0 & 16.9 \\
\hline $\mathrm{NH}_{4}-\mathrm{N}$ & $\mathrm{mgN} \mathrm{l}^{-1}$ & 26.0 & 29.2 & 25.0 & 21.5 & 24.6 & 27.0 & 60.8 & 1.3 & 3.5 \\
\hline $\mathrm{N}_{\text {tot }}$ & $\mathrm{mgN} \mathrm{l}^{-1}$ & 69.5 & --- & 57.0 & 58.5 & --- & 46.0 & 79.0 & --- & 28.0 \\
\hline $\mathrm{N}_{\text {tot filtered }}$ & $\mathrm{mgN} \mathrm{l}^{-1}$ & 61.3 & 57.0 & 56.0 & 56.5 & 43.5 & 44.0 & 63.0 & 25.8 & 25.5 \\
\hline $\mathrm{P}_{\text {tot }}$ & $\mathrm{mgP} \mathrm{l}^{-1}$ & 18.3 & --- & 14.6 & 13.8 & --- & 6.6 & 6.6 & --- & 2.2 \\
\hline $\mathrm{PO}_{4}-\mathrm{P}$ & $\mathrm{mgP} \mathrm{l}^{-1}$ & 13.4 & 12.0 & 12.3 & 10.3 & 4.2 & 3.7 & 4.5 & 0.3 & 0.6 \\
\hline Alk & $\mathrm{mgCaCO}_{3} \mathrm{l}^{-1}$ & 436 & 555 & 486 & 437 & 381 & 410 & 429 & 176 & 179 \\
\hline
\end{tabular}

\section{RESULTS AND DISCUSSION \\ Wastewater characterization}

ASM2d total COD includes the following components: inert soluble COD $\left(\mathrm{S}_{\mathrm{I}}\right)$, readily biodegradable $\mathrm{COD}\left(\mathrm{S}_{\mathrm{F}}\right)$, volatile fatty acids $\left(\mathrm{S}_{\mathrm{A}}\right)$, heterotrophic biomass $\left(\mathrm{X}_{\mathrm{H}}\right)$, nitrifying biomass $\left(\mathrm{X}_{\mathrm{AUT}}\right)$, phosphorus accumulating biomass $\left(\mathrm{X}_{\mathrm{PAO}}\right)$, storage products of PAOs ( $\left.\mathrm{X}_{\mathrm{PHA}}\right)$, inert particulate $\left(\mathrm{X}_{\mathrm{I}}\right)$ and slowly biodegradable organic matter $\left(\mathrm{X}_{\mathrm{S}}\right)$. The wastewater characterization was carried out following a physico-chemical separation technique as described in Penya-Roja et al. (2002).

Tabla 2. Wastewater characterization.

\begin{tabular}{llccc}
\hline Parameter & Unit & Elche A & Elche B & Elda \\
\hline $\mathrm{S}_{\mathrm{I}}$ & mgCOD l $^{-1}$ & 40 & 31 & 56 \\
$\mathrm{~S}_{\mathrm{F}}$ & mgCOD l $^{-1}$ & 326 & 286 & 229 \\
$\mathrm{~S}_{\mathrm{A}}$ & mgCOD l $^{-1}$ & 0 & 0 & 91 \\
$\mathrm{X}_{\mathrm{I}}$ & mgCOD l $^{-1}$ & 189 & 34 & 56 \\
$\mathrm{X}_{\mathrm{S}}$ & mgCOD l $^{-1}$ & 384 & 68 & 213 \\
$\mathrm{~S}_{\mathrm{NO} 3}$ & mgN l $^{-1}$ & 0.7 & 0 & 0 \\
$\mathrm{~S}_{\mathrm{NH} 4}$ & mgN l $^{-1}$ & 26.0 & 21.5 & 60.8 \\
$\mathrm{~S}_{\mathrm{PO} 4}$ & mgP l $^{-1}$ & 13.4 & 10.3 & 4.5 \\
\hline
\end{tabular}

\section{Calibration}

ASM2d model has been calibrated using the methodology developed by Penya-Roja et al. (2002). This methodology is based on the selective calibration of high influence kinetic and stoichiometric parameters by means of laboratory batch experiments using pilot plant biomass (off-line). These experiments include respirometric techniques and individualized analysis of the different processes carried out by heterotrophic, nitrifying and phosphorus accumulating microorganisms. Calibration and simulation were performed assuming steady-state conditions.

Determination of kinetic and stoichiometric parameters of heterotrophic organisms. Heterotrophic yield coefficient $\left(\mathrm{Y}_{\mathrm{H}}\right)$ was determined using respirometry (Figure 1). Heterotrophic rate constant for 
lysis $\left(\mathrm{b}_{\mathrm{H}}\right)$ was determined from global treatment of data obtained from the different assays making use of the global endogenous respiration rate (b') and equation (1). This b' was determined by a respirometric method using exponential fitting data (Figure 1).

$b^{\prime}\left(X_{H}+X_{A}+X_{P A O}\right)=\left(b_{H} X_{H}+b_{A} X_{A}+b_{P A O} X_{P A O}\right)\left(1-Y_{H}\left(1-f_{p}\right)\right)$

where:

$\mathrm{b}_{\mathrm{H}}, \mathrm{b}_{\mathrm{A}}, \mathrm{b}_{\mathrm{PAO}}$ are heterotrophic, nitrifying and phosphorus accumulating rate constant for lysis. $\mathrm{f}_{\mathrm{p}}$, fraction of non biodegradable biomass.
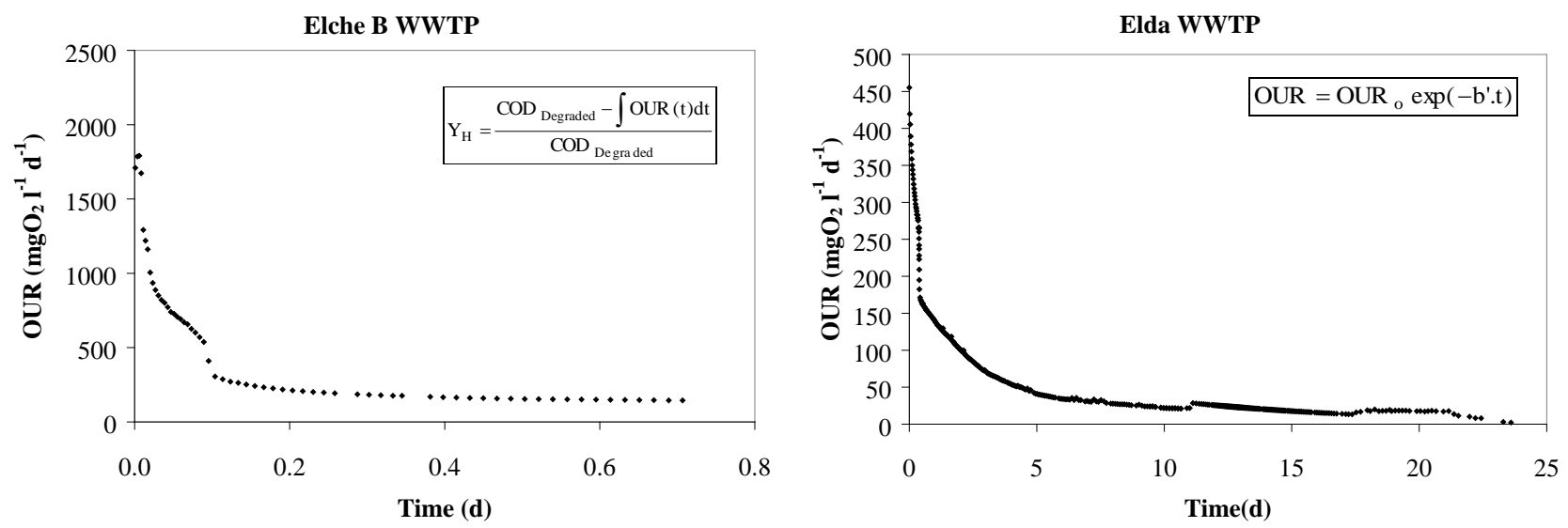

Figure 1. Time evolution of Oxygen Uptake Rate (OUR).

Maximum heterotrophic growth rate $\left(\mu_{\mathrm{H}}\right)$ and saturation coefficient for growth on $\mathrm{S}_{\mathrm{F}}\left(\mathrm{K}_{\mathrm{F}}\right)$ was determined applying the method described by Cech et al. (1984). In Figure 2 is represented the increase of the initial OUR with soluble COD for Elda WWTP.
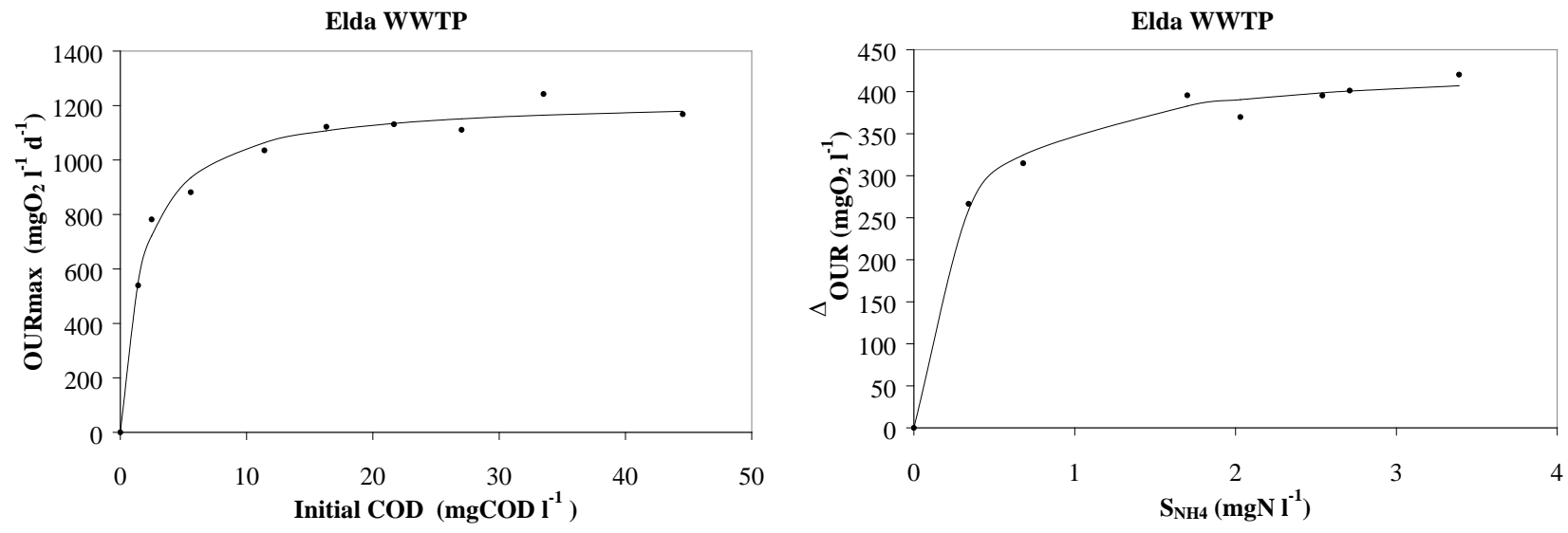

Figure 2. OUR versus soluble COD and ammonia.

The calibrated values obtained for heterotrophic kinetic and stoichiometric parameters are summarised in Table 3. The values obtained for the maximum growth rate for heterotrophic bacteria $\left(\mu_{\mathrm{H}}\right)$, for Elche WWTP, show that the reactor B growth rate is one magnitude grade lower than the one obtained for reactor A (0.74 and 2.64, respectively). It is a consequence of the low biodegradability of the substrate entering the reactor B. The $\mu_{\mathrm{H}}$ values for Elche-A and Elda are in the range of values observed by other authors (Stokes et al., 1993; Siegrist et al., 1995). The $\mathrm{K}_{\mathrm{F}}$ value for Elda WWTP (1.73) is close to the values proposed by Slide and Dare (1993). A reduction 
factor for denitrification was also calibrated for both plants showing values in accordance with literature (Henze et al., 1999; Sözen et al., 1998).

Determination of kinetic and stoichiometric parameters of nitrifying organisms. Nitrifying yield coefficient $\left(\mathrm{Y}_{\mathrm{A}}\right)$ was adopted from literature (Henze et al., 1999). Maximum nitrifying growth rate $\left(\mu_{\mathrm{A}}\right)$ and saturation coefficient for growth on $\mathrm{NH}_{4}-\mathrm{N}\left(\mathrm{K}_{\mathrm{NH} 4}\right)$ was determined in similar way to the heterotrophic organisms. In Figure 2, the increase of the initial OUR with ammonia concentration for Elda WWTP is represented. Nitrifying organisms rate constant for lysis $\left(b_{A}\right)$ was determined together with heterotrophic organisms and PAOs constant for lysis as was described before. The calibrated values obtained for autotrophic kinetic and stoichiometric parameters are summarised in Table 3. In Elche-A no nitrification took place because of the low SRT value ( $0.5 \mathrm{~d})$.

Inhibition problems were found for nitrifying microorganisms, especially in Elche WWTP, as a consequence of the industrial wastewater fraction. This inhibition is reflected in a low nitrifying growth rate value and in a high rate constant for lysis value.

Determination of kinetic and stoichiometric parameters of phosphorus accumulating organisms. Figure 3 shows three examples of laboratory batch experiments realized in order to obtain kinetic and stoichiometric parameters of PAOs (Table 3). The yield coefficient of PAOs (Y PAO) obtained for Elda (0.90) is higher than the ASM2d parameter (0.63). ASM2d does not differentiate between PAOs and glycogen accumulating organisms (GAOs). Therefore, ASM2d includes both types of organisms in a single population. Consequently, ASM2d uses a single group of parameters and kinetic equations for describing the processes of both bacteria. Furthermore, glycogen is not considered as intracellular stored specie in ASM2d. Thus, the COD associated with GAOs and glycogen would be rated as $\mathrm{X}_{\mathrm{PAO}}$. As a result, the value of $\mathrm{Y}_{\mathrm{PAO}}$ will be higher in a mixed population than in a pure population of PAOs (García-Usach, 2002). On the other hand, the value of Y $\mathrm{PAO}$ obtained for Elche-B was 0.70; it is close to the value proposed by Smolders (1995) for a pure population of PAOs (0.73).

The maximum amount of storable phosphorus obtained for Elda $\left(\mathrm{K}_{\mathrm{MAx}}=0.234 \mathrm{mgP}_{\mathrm{mgCOD}}{ }^{-1}\right)$ is lower than the ASM2d value (0.34), denoting the presence of GAOs in the plant. KMAX represents the maximum ratio $\mathrm{X}_{\mathrm{PP}} / \mathrm{X}_{\mathrm{PAO}}$, so as GAOs are considered as PAOs in ASM2d and they cannot store polyphosphate, the maximum ratio diminishes. The value of $\mathrm{K}_{\mathrm{MAX}}$ obtained for Elche-B WWTP was $0.30 \mathrm{mgP} \mathrm{mgCOD}^{-1}$. This value is close to the ASM2d value. Thus, the values obtained for $\mathrm{K}_{\mathrm{MAX}}$ and $\mathrm{Y}_{\mathrm{PAO}}$ suggest the presence of GAOs in Elda WWTP but not in Elche-B WWTP.
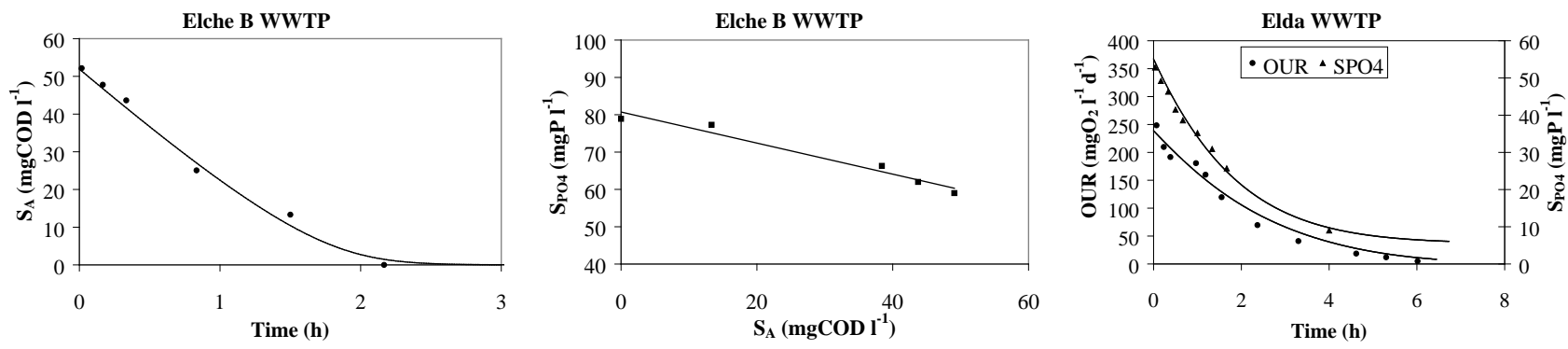

Figure 3. Examples of laboratory batch experiments realized in order to obtain kinetic and stoichiometric parameters of PAOs.

Under anaerobic conditions, PAOs and GAOs can store $S_{A}$ in the form of cell internal organic storage material (PHA). PAOs utilize the energy obtained from the hydrolysis of polyphosphate and glycogen degradation. On the other hand, the energy used by GAOs only comes from glycogen degradation without involvement of polyphosphate. This fact justifies the decrease of the $\mathrm{Y}_{\mathrm{PO} 4}$ 
value with the increase in GAOs population (Henze et al., 1995; Rodrigo et al., 1996). Besides, the population of GAOs increases with SRT (Satoh et al., 1994; Rodrigo et al., 1996; Manga et al., 2001). As has been stated before, the value obtained for $Y_{\text {PAO }}$ and $K_{M A X}$ indicates the presence of GAOs in Elda WWTP but not in Elche B WWTP. It is in agreement with SRT values of both WWTPs (Table 4). So, the $\mathrm{Y}_{\mathrm{PO} 4}$ value obtained for Elche-B plant $\left(0.42 \mathrm{mgP} \mathrm{mgCOD}^{-1}\right)$ is close to the ASM2d value (0.40) pointing out the absence of GAOs. However, the Y $\mathrm{PO}_{\mathrm{P}}$ value obtained for Elda WWTP was $0.46 \mathrm{mgP}_{\mathrm{mgCOD}}{ }^{-1}$. This value is much higher than the expected value for a mixed population of GAOs and PAOs. This fact can be explained with the high $\mathrm{pH}$ value at reactor (7.95). Smolders et al. (1994) reported that the value of $\mathrm{Y}_{\mathrm{PO} 4}$ is strongly influenced by the $\mathrm{pH}$ value. At $7.95 \mathrm{pH}$ value, the $\mathrm{Y}_{\mathrm{PO}}$ proposed by Smolders is $0.64 \mathrm{mgP} \mathrm{gCOD}^{-1}$ for a pure population of PAOs. In this way, the $\mathrm{Y}_{\mathrm{PO} 4}$ decrease associated with the presence of GAOs is compensated by the $\mathrm{pH}$ value.

Despite $\mathrm{K}_{\mathrm{IPP}}$ and qPP $_{\mathrm{P}}$ calibrated values differ from literature values, a good correspondence between the experimental and the simulated values was observed. The high values of both parameters are a consequence of the mathematical resolution. The high $\mathrm{K}_{\mathrm{IPP}}$ values compensate the high qPP values.

Table 3. Heterotrophic, nitrifying and PAO calibrated parameter values.

\begin{tabular}{|c|c|c|c|c|c|}
\hline Parameter & Unit & Elche A & Elche B & Elda & ASM2d \\
\hline $\mathrm{Y}_{\mathrm{H}}$ & mgCOD mgCOD $^{-1}$ & 0.57 & 0.53 & 0.65 & 0.63 \\
\hline$\mu_{\mathrm{H}}$ & $d^{-1}$ & 2.64 & 0.74 & 2.76 & 6.00 \\
\hline $\mathrm{K}_{\mathrm{F}}$ & $\operatorname{mgCOD~l^{-1}}$ & 3.68 & 4.04 & 1.73 & 4.00 \\
\hline $\mathrm{b}_{\mathrm{H}}$ & $\mathrm{d}^{-1}$ & 0.37 & 0.42 & 0.50 & 0.40 \\
\hline$\eta_{\mathrm{NO} 3}$ & & --- & 0.90 & 0.58 & 0.80 \\
\hline$\mu_{\mathrm{A}}$ & $\mathrm{d}^{-1}$ & --- & 0.55 & 0.74 & 1.00 \\
\hline $\mathrm{K}_{\mathrm{NH} 4}$ & $\mathrm{mgN} \mathrm{l}^{-1}$ & --- & 0.81 & 0.23 & 1.00 \\
\hline $\mathrm{b}_{\mathrm{A}}$ & $\mathrm{d}^{-1}$ & --- & 0.26 & 0.15 & 0.15 \\
\hline $\mathrm{Y}_{\mathrm{PO} 4}$ & $\mathrm{mgP} \mathrm{mgCOD}^{-1}$ & --- & 0.42 & 0.46 & 0.40 \\
\hline qPHA & $\mathrm{d}^{-1}$ & --- & 1.93 & 9.03 & 3.00 \\
\hline $\mathrm{K}_{\mathrm{A}}$ & $\mathrm{mgCOD} \mathrm{l}^{-1}$ & --- & 7.91 & 9.73 & 4.00 \\
\hline $\mathrm{Y}_{\mathrm{PAO}}$ & $\mathrm{mgCOD} \mathrm{mgCOD}^{-1}$ & --- & 0.71 & 0.90 & 0.63 \\
\hline$\mu_{\mathrm{PAO}}$ & $d^{-1}$ & --- & 1.15 & 2.13 & 1.00 \\
\hline $\mathrm{q}_{\mathrm{PP}}$ & $\operatorname{mgP} \operatorname{mgCOD}^{-1} \mathrm{~d}^{-1}$ & --- & 7.16 & 10.88 & 1.50 \\
\hline bРAO & $\mathrm{d}^{-1}$ & --- & 0.20 & 0.20 & 0.20 \\
\hline $\mathrm{K}_{\mathrm{PHA}}$ & $\mathrm{mgCOD} \mathrm{mgCOD}^{-1}$ & --- & 0.001 & 0.140 & 0.01 \\
\hline $\mathrm{K}_{\text {IPP }}$ & $\mathrm{mgP} \mathrm{mgCOD}^{-1}$ & --- & 0.24 & 0.49 & 0.02 \\
\hline $\mathrm{K}_{\text {MAX }}$ & $\mathrm{mgP} \mathrm{mgCOD}^{-1}$ & --- & 0.30 & 0.23 & 0.34 \\
\hline
\end{tabular}

\section{Simulation and upgrade}

Once the kinetic and stoichiometric parameters of the different microorganisms considered were determined, the activated sludge and effluent characteristics were simulated using the software DESASS (DEsign and Simulation of Activated Sludge Systems) (Seco et al., submitted). This software takes into account the sedimentation model proposed by Ribes et al. (2002) which considers the biological process that takes place in primary and secondary settlers.

The process configurations of both the actual and upgrade Elche and Elda WWTPs are presented in Figure 4. Moreover, Table 4 shows the operational data and hydraulic design parameters of the activated sludge treatment for both WWTPs. Aerated zone of the activated sludge tank behaves like two or three reactors in series depending on the dissolved oxygen concentration (DO) variation. 


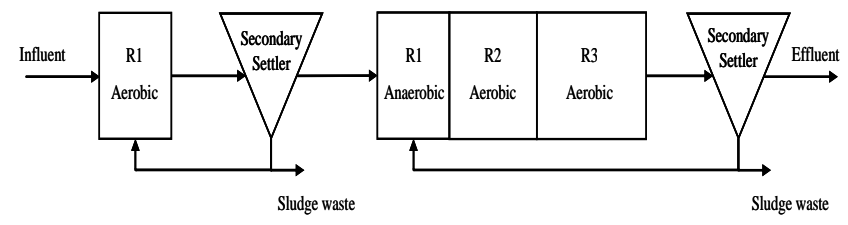

Elche WWTP (actual)

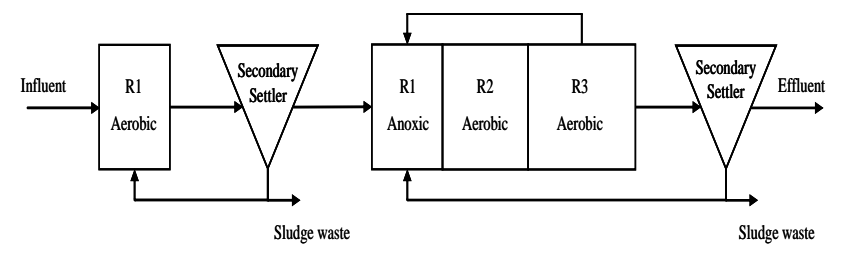

Elche WWTP (upgrade)

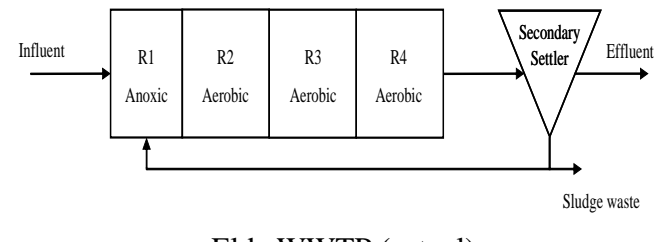

Elda WWTP (actual)

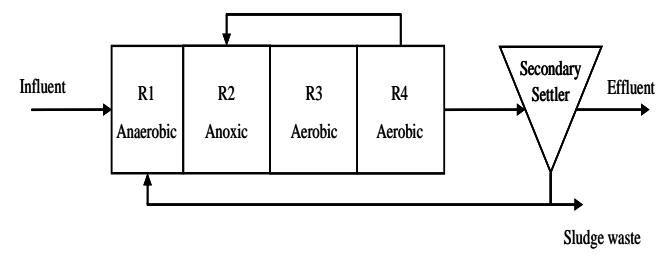

Elda WWTP (upgrade)

Figure 4. Wastewater treatment plant configurations.

Table 4. Operational data and hydraulic design parameters used for simulation.

\begin{tabular}{|c|c|c|c|c|c|c|}
\hline & \multicolumn{2}{|c|}{ Elche A } & \multicolumn{2}{|c|}{ Elche B } & \multicolumn{2}{|c|}{ Elda } \\
\hline & Actual & Upgra. & Actual & Upgra. & Actual & Upgra. \\
\hline Total flow $\left(\mathrm{m}^{3} \mathrm{~d}^{-1}\right)$ & 26546 & 26546 & 22920 & 25227 & 7960 & 7960 \\
\hline $\operatorname{SRT}(d)$ & 0.5 & 0.5 & 7 & 15 & 11 & 13 \\
\hline $\mathrm{T}\left({ }^{\circ} \mathrm{C}\right)$ & 25 & 22 & 26 & 22 & 27 & 20 \\
\hline Activated sludge volume $\left(\mathrm{m}^{3}\right)$ & 1700 & 1700 & 8400 & 8400 & 3437 & 3437 \\
\hline $\mathrm{R} 1$ (total volume $\%$ - mgDO l ${ }^{-1}$ ) & $100-1$ & $100-2$ & $13-0$ & $13-0$ & $8-0$ & $8-0$ \\
\hline R2 (total volume $\%-$ mgDO l$^{-1}$ ) & --- & --- & $37-2.9$ & $37-3$ & $32-0.3$ & $20-0$ \\
\hline R3 (total volume $\%$ - mgDO l-1) & --- & --- & $50-1.5$ & $50-3$ & $32-0.7$ & $50-2$ \\
\hline R4 (total volume $\%$ - mgDO l-1) & --- & --- & --- & --- & $22-3.6$ & $22-2$ \\
\hline No. secondary settler & 2 & 2 & 2 & 2 & 1 & 1 \\
\hline Settler diameter (m) & 25 & 25 & 28 & 28 & 32 & 32 \\
\hline Settler depth (m) & 3 & 3 & 2.3 & 2.3 & 3.5 & 3.5 \\
\hline Sludge recycle flow $\left(\mathrm{m}^{3} \mathrm{~d}^{-1}\right)$ & 20823 & 20171 & 20400 & 63787 & 3533 & 7740 \\
\hline Internal recycle flow $\left(\mathrm{m}^{3} \mathrm{~d}^{-1}\right)$ & --- & --- & --- & 100908 & --- & 31840 \\
\hline
\end{tabular}

Results from simulation (Table 5 and Table 6) showed a good correspondence with experimental data demonstrating not only the consistence of the calibration methodology but also the usefulness of the software DESASS to reproduce the behaviour of each WWTP calibrated.

Table 5. Actual (experimental), simulated and upgraded effluent values.

\begin{tabular}{|c|c|c|c|c|c|c|c|c|c|c|}
\hline \multirow{2}{*}{ Parameter } & \multirow{2}{*}{ Unit } & \multicolumn{3}{|c|}{ Elche A } & \multicolumn{3}{|c|}{ Elche B } & \multicolumn{3}{|c|}{ Elda } \\
\hline & & Actual & Sim. & Upgra. & Actual & Sim. & Upgra. & Actual & Sim. & Upgra. \\
\hline TSS & $\mathrm{mg} \mathrm{l}^{-1}$ & 63 & 61 & 64 & 19 & 13 & 19 & 22 & 20 & 27 \\
\hline VSS & $\mathrm{mg} \mathrm{l}^{-1}$ & 54 & 48 & 50 & 15 & 10 & 16 & 18 & 17 & 23 \\
\hline $\mathrm{COD}_{\text {total }}$ & $\mathrm{mgCOD} \mathrm{l}^{-1}$ & 375 & 370 & 425 & 71 & 70 & 72 & 84 & 87 & 97 \\
\hline $\mathrm{COD}_{\text {filtered }}$ & $\mathrm{mgCOD} \mathrm{l}^{-1}$ & 285 & 287 & 332 & 57 & 56 & 45 & 58 & 56 & 57 \\
\hline $\mathrm{NO}_{3}-\mathrm{N}$ & $\mathrm{mgN} \mathrm{l}^{-1}$ & 0 & 0.7 & 0.7 & 0.5 & 0.2 & 25.1 & 16.9 & 22.1 & 9.8 \\
\hline $\mathrm{NH}_{4}-\mathrm{N}$ & $\mathrm{mgN} \mathrm{l}^{-1}$ & 25.0 & 30.4 & 27.9 & 27.0 & 30.3 & 5.2 & 3.5 & 3.7 & 1.1 \\
\hline $\mathrm{N}_{\text {tot }}$ & $\mathrm{mgN} \mathrm{l}^{-1}$ & 57.0 & 56.8 & 59.6 & 46.0 & 49.6 & 35.4 & 28.0 & 29.8 & 15.8 \\
\hline $\mathrm{N}_{\text {tot filtered }}$ & $\mathrm{mgN} \mathrm{l}^{-1}$ & 56.0 & 54.2 & 57.4 & 44.0 & 48.7 & 34.4 & 25.5 & 26.5 & 11.7 \\
\hline $\mathrm{P}_{\text {tot }}$ & $\mathrm{mgP}^{-1}$ & 14.6 & 13.8 & 14.2 & 6.6 & 6.1 & 13.2 & 2.2 & 1.2 & 1.2 \\
\hline $\mathrm{PO}_{4}-\mathrm{P}$ & $\mathrm{mgP} \mathrm{l}^{-1}$ & 12.3 & 12.8 & 12.9 & 3.7 & 5.2 & 12.9 & 0.6 & 0.3 & 0.1 \\
\hline
\end{tabular}


Once the calibration and simulation process was finished, a performance study for each WWTP was made. Both WWTPs showed a non-optimal nutrient removal due to several causes. The main problems lay in poor hydraulic conditions, inappropriate reactor configuration and foam accumulation that prevented a good aeration. The proposed modifications focused on reactor configuration and operation strategies (Figure 4 - Table 4), with no changes on reaction volume, considering total nitrification $\left(\mathrm{N}-\mathrm{NH}_{4}<1 \mathrm{mg} \mathrm{l}^{-1}\right)$ aim.

Table 6. Actual (experimental), simulated and upgraded mixed liquor values.

\begin{tabular}{|c|c|c|c|c|c|c|c|c|c|c|}
\hline \multirow{2}{*}{ Parameter } & \multirow{2}{*}{ Unit } & \multicolumn{3}{|c|}{ Elche A } & \multicolumn{3}{|c|}{ Elche B } & \multicolumn{3}{|c|}{ Elda } \\
\hline & & Actual & Sim. & Upgra. & Actual & Sim. & Upgra. & Actual & Sim. & Upgra. \\
\hline TSS & $\mathrm{mg} \mathrm{l}^{-1}$ & 2428 & 2644 & 2779 & 2113 & 2180 & 3381 & 3772 & 3344 & 4404 \\
\hline VSS & $\mathrm{mg} \mathrm{l}^{-1}$ & 1917 & 2073 & 2182 & 1522 & 1620 & 2757 & 2905 & 2890 & 3866 \\
\hline $\mathrm{COD}_{\text {total }}$ & $\mathrm{mgCOD} \mathrm{l}^{-1}$ & 3942 & 3949 & 4395 & 2327 & 2338 & 4784 & 5025 & 5141 & 6697 \\
\hline
\end{tabular}

At Elche WWTP the upgrade consisted of recovering the nitrogen removal process. In order to improve nitrification in Elche-B without increasing reactor volumes, a SRT increase was proposed. Because of the increase in nitrate concentration (Table 5), the anaerobic reactor was turned into an anoxic one. Moreover, an internal recirculation flow between the aerobic and the anoxic reactor was projected with the aim of improving denitrification. As a result of these modifications, biological phosphorus removal was eliminated.

At Elda WWTP external baffles between the anoxic and the aerobic zone caused foam accumulation limiting the aeration level. To reduce this foam accumulation, superficial and bottom narrow passages would be necessary between reactors. Anaerobic and anoxic reactors after upgrading originated a nitrogen removal efficiency rise, from $64 \%$ to $80 \%$. Furthermore, biological phosphorus removal efficiency increased from $67 \%$ to $82 \%$.

\section{CONCLUSIONS}

The values of calibrated kinetic and stoichiometric parameters showed an important dependence on wastewater characteristics, representing both systems reasonably well. Inhibition problems were found for nitrifying microorganisms probably as a result of an industrial component in wastewater. Moreover, the presence of glycogen accumulating organisms was observed. The good simulation results have shown not only the consistence of the calibration methodology but also the usefulness of the DESASS software.

Both WWTPs showed a non-optimal nutrient removal. Modifications focused on reactor configuration and operation strategies were proposed to improve biological nitrogen removal at Elche WWTP and both nitrogen and phosphorus biological removal at Elda WWTP.

It can therefore be concluded that the obtained results highlight the advantage of using calibration methodology and mathematical models to find optimum solutions for the upgrading of existing plants.

\section{ACKNOWLEDGEMENT}

The authors express their acknowledgements to the Entitat Pública de Sanejament d'Aigües Residuals de la Comunitat Valenciana for their financial support. 


\section{REFERENCES}

Cech J.S., Chudoba J. and Grau P. (1984). Determination of kinetics constants of activated sludge microorganisms. Wat. Sci. Tech., 17, 259-272.

García-Usach F. (2002). Influence of sludge retention time and temperature on biological matter and nutrient removal of wastewaters. PhD thesis, Department of Hydraulic Engineering and Environment, Universitat Politécnica of Valencia.

Henze M., Gujer W., Mino T., Matsuo, Wentzel M.C., Marais G.v.R. (1995). Activated Sludge Model No. 2. IAWQ Scientific and Technical Report No 3, IAWPRC, London. ISBN 190022000.

Henze M., Gujer W., Mino T., Matsuo, Wentzel M.C., Marais G.v.R. and Van Loosdrecht M.C.M. (1999). Activated Sludge Model No. 2d. Wat. Sci. Tech., 39(1), 165-182.

Manga J., Ferrer J., García-Usach F. and Seco A. (2001). A modification to the Activated Sludge No. 2 based on the competition between phosphorus-accumulating organisms and glycogenaccumulating organisms. Wat. Sci. Tech., 43, (11), 161-171.

Penya-Roja J.M., Seco A., Ferrer J., Serralta J. (2002). Calibration and validation of Activated Sludge Model No. 2d for Spanish municipal wastewater. Environ. Technol., 23, 849-862.

Ribes J., Ferrer J., Bouzas A., Seco A. (2002). Modelling of an activated primary settling tank including the fermentation process and VFA elutriation. Environ. Technol., 23, 1147-1156.

Rodrigo M. A., Seco A., Ferrer J. and Penya-Roja, J. M. (1996). Influence of sludge age on enhanced phosphorus removal in biological systems. Wat. Sci. Tech., 34, (1/2), 41-48.

Satoh H., Mino T. and Matsuo, T. (1994). Deterioration of enhanced biological phosphorus removal by the domination of microorganisms without polyphosphate accumulation. Wat. Sci. Tech., 30, 203-211.

Seco A., Ribes J., Serralta J. and Ferrer J. Biological nutrient removal model No.1 (BNRM1) (2003). Submitted to this congress.

Siegrist H., Krebs P., Bühler R., Purtschert I., Röck C. and Rufer R. (1995). Denitrification in secondary clarifiers. Wat. Sci. Tech., 31, (2), 205-214.

Slide H. A. and Dare H. P. (1993). Measuring maximum specific growth rate and half saturation coefficient for activated sludge system using a freeze concentration technique. Wat. Res., 27, 1793-1795.

Smolders G.J.F., van der Meij J., van Loosdercht M.C.M. and Heijnen, J.J. (1994). Model of the anaerobic metabolism of the biological phosphorus removal process: Stoichiometry and $\mathrm{pH}$ influence. Biotechnol. Bioeng., 43, 461-470.

Smolders G. J. F. (1995). A structured metabolic model for the anaerobic and aerobic stoichiometry of the biological phosphorus removal process. Biotechnol. Bioeng., 47, 277-287.

Sözen S., Ubay Çokgör D., Orhon D. and Henze, M. (1998). Respirometric analysis of activated sludge behaviour-II. Heterotrophic growth under aerobic and anoxic conditions. Wat. Sci. Tech., 32, (2), 476-488.

Standard Methods for the Examination of Water and Wastewater (1998). 20 $0^{\text {th }}$ edn, American Public Health Association, American Water Works Association and Water Environment Federation , Washington DC, USA.

Stokes L., Takacs I., Watson B. and Watts J. B. (1993). Dynamic modelling of an ASPsewage works- a case study. Wat. Sci. Tech., 28, (11/12), 151-161.

Water Research Commission (1992). Simple titration procedures to determine $\mathrm{H}_{2} \mathrm{CO}_{3}{ }^{*}$ alkalinity and short-chain fatty acids in aqueous solutions containing known concentrations of ammonium, phosphate and sulphide weak acid/bases, Report No. TT 57/92, Water Research Commission, University of Cape Town, Pretoria, Republic of South Africa. 